\title{
Acetylene Reduction Activity in Free-Living Cultures of Rhizobia
}

\author{
T, KANESHIRO, C. D. CROWELL, AND R. F. HANRAHAN, JR. \\ Northern Regional Research Center, Agricultural Research Service, U.S. Department of Agriculture, \\ Peoria, Illinois 61604
}

\begin{abstract}
A survey of 272 free-living rhizobia strains showed that a majority of the Rhizobium japonicum and unclassified Rhizobium isolates are capable of both growth and acetylene reduction on a Casamino Acids-minimal medium. Two other taxonomic categories of Rhizobium were discernible: $R$. meliloti and $R$. trifolii, which grow but do not reduce acetylene; and $R$. leguminosarum, which fails to grow on the minimal medium. Sixty-nine strains were acetylene reducers obtained from root nodules of the plant hosts: Albizzia, Cassia (partridge pea), Baptisia (wild indigo), Crotalaria, Ulex (thornbroom), Indigofera, Lespedeza, Desmodium (Florida beggarweed), Arachis (peanut), Phaseolus, Strophostyles, Stizolobium (velvet bean), Pueraria (kudzu), Vigna (cowpea), Erythrina, and Glycine (soybean). The extent of acetylene reduction varied depending on both the Rhizobium strain and $\mathrm{O}_{2}$ tension, suggesting that reduction activity differs according to the cellular organization of individual strains.
\end{abstract}

Taxonomic approaches to separate rhizobia have included: nutritional and antigenic specificities (20); deoxyribonucleic acid base composition (4); deoxyribonucleic acid homology (9); and glutamate and phosphate uptakes by cells (21). Based on such studies, rhizobia that have been classified fall generally into three groups: (i) Rhizobium leguminosarum-R. phaseoli-R. trifolii, (ii) $R$. meliloti, and (iii) $R$. japonicum$R$. lupini. Many other fast- and slow-growing rhizobia, however, await specific designation. The introduction of acetylene reduction as an assay for nitrogen fixation capability $(3,5,8)$ and the production of acetylene-reducing enzyme by Rhizobium strains under nonsymbiotic conditions $(2,11,13,15,17,19)$ have made possible a rapid survey in an attempt to categorize 272 strains of rhizobia from the NRRL collection.

To acknowledge the years Lewis $\mathrm{T}$. Leonard and others (U.S. Department of Agriculture [USDA], Beltsville, Md.) spent in isolating and collecting Rhizobium strains from plant root nodules, we at the Northern Regional Research Center have designated this partial acquisition by L-numbers. A succession of individuals including U. M. Means (USDA, Beltsville, Md.), R. E. Gordon (Institute of Microbiology, Rutgers University, N.J.), and W. C. Haynes (USDA, Peoria, Ill.) have maintained this lyophilized collection. Their record indicates the host plant of each Rhizobium isolate and, where possible, the species corresponding to the International Biological Programme (IBP) World Catalogue of Rhizobium Collections (1). Conse- quently, this L-collection should help to clarify problems related to the classification of Rhizobium strains.

\section{MATERIALS AND METHODS}

Cultivation of strains. The lyophilized Rhizobium strains and corresponding record of the L-collection were obtained from L. K. Nakamura (Agricultural Research Service Culture Collection, Peoria, Ill.). The complete list (NRRL numbers L-1 through L-344) includes 29 strains that failed to grow and consequently were discarded over the years. Of the remaining 315 lyophilized strains in the present L-collection, 32 failed to grow on conventional yeast extract-mannitol-soil extract agar (YMS medium $111 ; 18$ ) and were omitted from this survey. No further attempt was made to ensure purity of each culture, but a small number of cultures were discarded since they yielded more than one distinct type of colony or growth on the various media and were not consistent with the recorded growth rate before lyophilization. A cowpeatype strain, Rhizobium $\mathrm{sp}$. $32 \mathrm{H1}$, was generously provided by J. C. Burton (Nitragin Co., Milwaukee, Wis.).

The lyophilized strains were suspended in a small volume of yeast extract-malt extract broth before transfer to YMS slants. After 5 to 20 days of incubation at $25^{\circ} \mathrm{C}$, a loopful of culture was transferred to a "preconditioning" liquid medium, adjusted to $\mathrm{pH} 6.8$, which contained per liter: L-glutamic acid, 1 g; mannitol, $5 \mathrm{~g}$; potassium gluconate, $5 \mathrm{~g} ; \mathrm{KH}_{2} \mathrm{PO}_{4}, 1 \mathrm{~g}$; yeast extract, $0.5 \mathrm{~g} ; \mathrm{MgSO}_{4} \cdot 7 \mathrm{H}_{2} \mathrm{O}, 0.2 \mathrm{~g} ; \mathrm{CaCl}_{2} \cdot 2 \mathrm{H}_{2} \mathrm{O}, 0.08$ $\mathrm{g}$; and Fe-Mo solution, $4 \mathrm{ml}$. Stock Fe-Mo solution contained $1 \mathrm{mg}$ of $\mathrm{Fe}$ and $0.1 \mathrm{mg}$ of Mo metals per $\mathrm{ml}$. The liquid cultures, $10 \mathrm{ml}$ each in a $50-\mathrm{ml}$ Erlenmeyer flask, were incubated aerobically on a rotary shaker $(250 \mathrm{rpm})$ for 3 days at $25^{\circ} \mathrm{C}$. All cultures were subsequently incubated for an additional day without shaking, since production of acetylene-reducing en- 
zyme(s) could be affected adversely by atmospheric oxygen $(5,11,16,22)$.

Growth in Casamino Acids-minimal medium. A $0.5-\mathrm{ml}$ inoculum was added to a serum vial (of approximately $20.5 \mathrm{ml}$ total capacity) that contained $5.5 \mathrm{ml}$ of Casamino acids-agar minimal medium. This medium, adjusted to $\mathrm{pH} 6.8$, contained per liter: saltfree Casamino Acids (Nutritional Biochemicals Corp.), $1.5 \mathrm{~g}$; potassium gluconate, $6 \mathrm{~g} ; \mathrm{KH}_{2} \mathrm{PO}_{4}, 6 \mathrm{~g}$; mannitol, $3 \mathrm{~g} ; \mathrm{MgSO}_{4} \cdot 7 \mathrm{H}_{2} \mathrm{O}, 0.2 \mathrm{~g} ; \mathrm{CaSO}_{4} \cdot 2 \mathrm{H}_{2} \mathrm{O}, 0.05 \mathrm{~g}$; agar, $10 \mathrm{~g}$; and Fe-Mo citrate solution, $20 \mathrm{ml}$. The Fe-Mo citrate stock solution was a mixture of $335 \mathrm{mg}$ of ferric citrate and $73 \mathrm{mg}$ of sodium molybdate stirred in 200 $\mathrm{ml}$ of warm water and acidified with citric acid. This modified Keister medium (11) was used to determine growth and ability of cultures to reduce acetylene.

For quantitative growth determinations, the mass of bacterial growth was gently rubbed off the agar surface to form a saline suspension $(10 \mathrm{ml}$ of $0.85 \%$ $\mathrm{NaCl})$, centrifuged-washed $(5 \mathrm{ml})$, and suspended in either 2.5 or $5.0 \mathrm{ml}$ of distilled water. After $1 \mathrm{~N}$ sodium hydroxide digestion for $1 \mathrm{~min}$ in a boiling-water bath, the cellular protein per vial was measured by a colorimetric Lowry method (14) and compared with a nonboiled standard of bovine serum albumin.

Acetylene reduction test. Each strain was cultivated in duplicate vials for 5 days at $28^{\circ} \mathrm{C}$. The vials contained $15 \mathrm{ml}$ of gas phase each and were sealed with silicone rubber caps. In contrast to neoprene caps, the silicone rubber caps were found to leak slowly an undetermined amount of air. This leakage presumably gave the proper $\mathrm{O}_{2}$ tension $(11,12)$ required for acetylene-reducing activity. Duplicate cultures were exposed to atmospheres of either $90 \%$ air or argon containing 10\% acetylene. After 2 and 5 days of exposure to acetylene, $1-\mathrm{ml}$ samples were withdrawn from the culture vials and analyzed by gas chromatography with a hydrogen flame ionization detector. The column $(2 \mathrm{~mm}$ by $150 \mathrm{~cm})$ of Poropak R polymeric beads was maintained at $65^{\circ} \mathrm{C}(3)$. Reduction of acetylene to ethylene was determined by the peak height relative to a standard of $50 \mathrm{nmol}$ of ethylene.

\section{RESULTS}

Growth of culture on a preconditioning medium. Lyophilized cultures of dormant rhizobia were initially grown on YMS medium at $25^{\circ} \mathrm{C}$. Of the 283 strains that grew on YMS, 95 were recorded as "slow growers," requiring 5 days or longer to give visible growth. The slow growth of rhizobia did not correlate noticeably with specific plant hosts. However, a majority (41 strains) of the 69 isolates reducing acetylene were slow growing when cultivated directly from their lyophilized state onto YMS slants.

Eleven of the 283 strains also failed to grow when cultivated aerobically in an enriched preconditioning liquid medium. Consequently, only 272 strains were considered in this taxonomic survey for the presence of acetylene-reducing activity.

Growth leading to enzyme production.
The survey showed that the liquid medium originally used by Keister $(6,11)$ to cultivate acetylene-reducing Rhizobium strains may be modified to categorize a whole collection rapidly. In addition to the soft-agar surface, the culturaltest condition was further modified by (a) preconditioning growth in an enriched liquid medium containing L-glutamate, mannitol, gluconate, and yeast extract and (b) subsequent incubation of stationary cultures in $10 \%$ acetylene with either $90 \%$ air or argon as the major atmospheric gas phase component.

Figure 1 illustrates that the activity of $R$. japonicum test strain L-259, one of the most active acetylene reducers found in the survey, is similar to that of strain $32 \mathrm{Hl}$, isolated from a Crotalaria paulina plant (J. C. Burton) and which has been generally used to study acetylene reduction $(6,11,13,15,17)$. Strains L-259 and $32 \mathrm{H} 1$ each produced up to $275 \mathrm{nmol}$ of ethylene per day per $\mathrm{mg}$ of protein. However, total yield of protein (Fig. 1) indicated that L259 grew slightly faster than $32 \mathrm{H} 1$ on the Casamino Acids-minimal medium. With both strains, acetylene-reducing activity was detectable after a lag period of 0.5 to 1 day after exposure to the acetylene-argon atmosphere.

Plant hosts yielding positive Rhizobium strains. Table 1 lists the acetylene-reducing Rhizobium cultures according to plant hosts. Although an insufficient number for statistical evaluation were isolated in many instances, all three subfamilies of Leguminosae yielded acetylene-reducing rhizobia. Genera of plant hosts

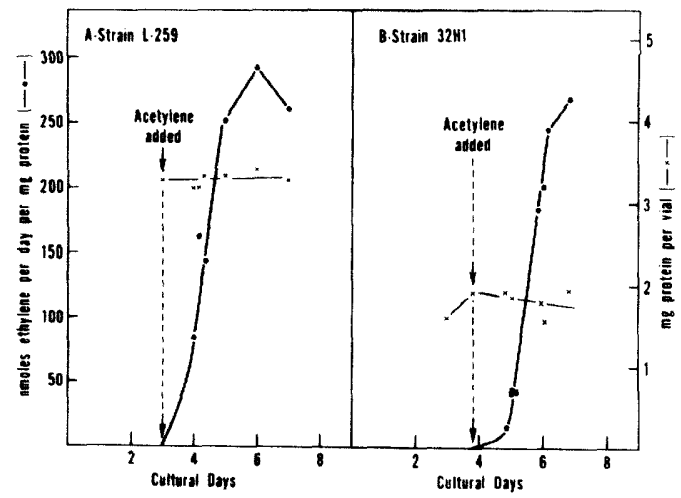

FIG. 1. Comparison of acetylene-reducing activity (O) of (A) $R$. japonicum test strain $L-259$ with activity of $(B)$ comparison strain $32 \mathrm{H1}$. At the designated times, all vials were sealed and exposed to an atmosphere of $10 \%$ acetylene with $10 \%$ air and $80 \%$ argon. Acetylene reduction was measured by gas-liquid chromatographic (3) analysis of the ethylene produced; growth was estimated as the milligrams of cell protein per vial $(\times)$. 
TABLE 1. Location in the family Leguminosae ${ }^{a}$ of plant hosts that yield acetylene-reducing rhizobia

\begin{tabular}{|c|c|c|c|}
\hline \multirow{2}{*}{ Genus of plant host ${ }^{a}$} & \multicolumn{3}{|c|}{$\begin{array}{c}\text { No. of acetylene-reducing } \\
\text { strains }^{b}\end{array}$} \\
\hline & $\begin{array}{c}\text { Posi- } \\
\text { tive }\end{array}$ & $\begin{array}{c}\text { Nega- } \\
\text { tive }\end{array}$ & $\begin{array}{l}\text { Non- } \\
\text { growing }\end{array}$ \\
\hline
\end{tabular}

Subfamily 1. Mimoso-

$$
\text { ideae }
$$

Acacia

Albizzia

Desmanthus

Subfamily 2. Caesalpinioideae

Cassia

Subfamily 3. Lotoideae

Tribe 2. Podalyrieae

Baptisia .......

Tribe 3. Genisteae

Crotalaria

Lupinus

Ulex

Tribe 4. Trifolieae

Medicago

Melilotus

Trifolium

Trigonella

Tribe 5. Loteae

Anthyllis

Lotus

Tribe 6. Galegeae

Amorpha, Cyamopsis, Petalostemon

Astragalus

Caragana, Psoralea,

Sesbania

Indigofera

Robinia

Tribe 7. Hedysareae

Arachis

Coronilla

Desmodium

Hedysarum, Onobry. chis, Ornithopus

Lespedeza

Tribe 9. Vicieae

Vicia

Cicer

Tribe 10. Phaseoleae

\begin{tabular}{|c|c|c|}
\hline Dolichos . . . . . . . & $\mathbf{0}$ & 1 \\
\hline Erythrina & 1 & $\mathbf{0}$ \\
\hline Glycine & 32 & 12 \\
\hline Phaseolus & 7 & 2 \\
\hline Pueraria & 1 & 0 \\
\hline Stizolobium & 1 & 0 \\
\hline Strophostyles & 1 & 2 \\
\hline Vigna ......... & 3 & 1 \\
\hline
\end{tabular}

${ }^{a}$ Classified according to Heywood (10).

${ }^{b}$ Categorized by a combination of cultural growth and acetylene reduction tests in a Casamino Acids medium; e.g., negative strains grew but did not reduce acetylene, whereas nongrowing strains failed to grow on the minimal medium. that gave the largest numbers of positive cultures include: Crotalaria (7 isolates from $C$. sagittalis, C. juncea, C. alata, C. incana, and C. maxillaris); Indigofera (4 isolates from $I$. hirsuta); Vigna (3 isolates from cowpea); Phaseolus (7 isolates from $P$. acutifolius - tepary or moth bean, $P$. lunatus-lima bean, $P$. aureus-mung bean); and Glycine (32 isolates from soybean). In contrast, rhizobia isolated from 32 different alfalfa and clover species (Trifolieae tribe) failed to reduce acetylene.

Rhizobium categories reducing acetylene. It is a prerequisite of the test that all of the strains must grow on the Casamino Acidsagar minimal medium. Of the 272 isolates tested, only 202 gave visible growth. Therefore, the overall proportion of positive cultures was 69 of the 202 (Table 2) growing strains, or approximately $34 \%$. $R$. japonicum isolates, representing $73 \%$ of such strains that grew on the minimal medium, reduced acetylene. A relationship to $R$. japonicum is suggested by the observation that a majority (73\%) of the unclassified Rhizobium strains isolated from other plants of the Phaseolae tribe also reduced acetylene. Similarly, $60 \%$ of the remaining category III strains isolated from specific plants of the cowpea group (4) reduced acetylene.

Although a majority of category III strains reduced acetylene, the diversity in this category indicates a serious limitation of using acetylene reduction by itself as a taxonomic trait. Even so, it is noteworthy that, whereas $73 R$. meliloti and $\boldsymbol{R}$. trifolii strains grew on the Casamino Acids-minimal medium, category I organisms uniformly failed to reduce acetylene.

Since $R$. leguminosarum and $R$. phaseoli strains (category II) grew sparingly or not at all on the minimal medium, their acetylene-reducing capability could not be measured. Other $R$. leguminosarum strains (NRRL B-509 and B606) not in the Leonard collection have also failed to grow on the Casamino Acids medium. Another problem was encountered with $R$. $l u$ pini isolates: only 4 of the original 21 isolates survived the lyophilization-storage procedure and grew in the preconditioning medium. Therefore, the four $R$. lupini strains listed in Table 2 may not be typical of the species. It is indeed puzzling that $R$. lupini strains, which are isolated from plants related to Crotalaria, are so different in cultural growth and acetylene reduction from other rhizobia obtained from Crotalaria. Since a deoxyribonucleic acid and metabolic relationship $(4,9,21)$ is found with $R$. japonicum, $\boldsymbol{R}$. lupini is presumably a category III organism.

The data summarized in Table 3 permit an arbitrary designation of two physiological types, 
TABLE 2. Rhizobium classification of root nodule isolates in relation to acetylene reduction

\begin{tabular}{|c|c|c|c|}
\hline \multirow{2}{*}{$\begin{array}{l}\text { Rhizobium classified in } \\
\text { IBP Catalogue (1) and } \\
\text { cultural category }\end{array}$} & \multicolumn{3}{|c|}{$\begin{array}{l}\text { No. of acetylene-reducing } \\
\text { strains }^{b}\end{array}$} \\
\hline & $\begin{array}{l}\text { Posi- } \\
\text { tive }\end{array}$ & $\begin{array}{c}\text { Nega- } \\
\text { tive }\end{array}$ & $\begin{array}{l}\text { Non- } \\
\text { growing }\end{array}$ \\
\hline \multicolumn{4}{|l|}{ Category I } \\
\hline R. meliloti & 0 & 39 & 6 \\
\hline R. trifolii & 0 & 34 & 24 \\
\hline $\begin{array}{l}\text { Unclassified strains } \\
\text { from host tribes, } 5 \text {, } \\
6 \text {, and } 9\end{array}$ & 0 & 23 & 10 \\
\hline \multicolumn{4}{|l|}{ Category II } \\
\hline R. leguminosarum & 0 & 0 & 2 \\
\hline R. phaseoli & 0 & 1 & 4 \\
\hline R. lupinic & 0 & 4 & 0 \\
\hline \multicolumn{4}{|l|}{ Category III } \\
\hline R. japonicum & 32 & 12 & 14 \\
\hline $\begin{array}{l}\text { Unclassified strains } \\
\text { from Phaseoleae } \\
\text { plants }\end{array}$ & 14 & 5 & 2 \\
\hline $\begin{array}{l}\text { Unclassified strains } \\
\text { from host tribes } 2,3 \text {, } \\
\text { and } 7 \text { plus Indigo- } \\
\text { fera, Albizzia, and } \\
\text { Cassia. }\end{array}$ & 23 & 14 & 7 \\
\hline
\end{tabular}

${ }^{a}$ NRRL strains, generally grouped in numerical order, include: $R$. meliloti (L-44 to L-89, L-169, and L-170); $R$. trifolii (L-90 to L-151, L-153 to L-158); unclassified category I strains (L-159 to L-168, L-171 to $\mathrm{L}-177, \mathrm{~L}-182$ to $\mathrm{L}-200$, and $\mathrm{L}-230$ to $\mathrm{L}-232$ except for discarded strains L-164, L-167, and L-174); $R$. leguminosarum (L-234 and L-235); $R$. phaseoli (L-318 to L-321, L-330); $R$. lupini (L-26, L-31, L-42, L-201); $R$. japonicum (L-236 to L-308 except for discarded strains L-239, L-240, L-244, L-270, L-275, and L-283);
TABLE 2-Continued

strains from Phaseoleae hosts (L-310 to L-315, L-322 to $\mathrm{L}-329, \mathrm{~L}-331$ to $\mathrm{L}-341$, and L-343 except for discarded strains L-312 and L-340); and category III strains from diverse host plants (L-2 to L-4, L-7 to L9, L-11 to L-19, L-21, L-22, L-43, L-178 to L-181, L202 to L-228, and L-344). Among these strains, there are a number that did not grow in any of the cultural media. Strains that are not part of this survey since they did not grow either on YMS medium or in the preconditioning liquid medium are: (category I) [L-57, L-66, L-76], [L-106, L-107, L-108, L-112, L-113, L-142, L-145, L-150, L-153, L-155], [L-189, L-197, and L-199]; (category III) [L-236, L-237, L-247, L-249, L261, L-263, L-268, L-282, L-305], [L-313, L-325], [L-8, L-16, L-209, L-222, L-223, L-225, and L-226]. Two other strains, L-1 and L-10, are not listed above since they were isolated from unusual Acacia and Desmanthus host plants, respectively, and were insufficient in number to be categorized. These strains are listed in Table 1. The surveyed strains that did not grow on the Casamino Acids minimal medium are: (category I) [L-44, L-51, L-53, L-65, L-67, L-68], [L-95, L-96, L98 to $\mathrm{L}-103, \mathrm{~L}-110, \mathrm{~L}-111, \mathrm{~L}-115, \mathrm{~L}-116, \mathrm{~L}-118$ to $\mathrm{L}-$ 121, L-123, L-124, L-126, L-127, L-128, L-131, L-141, L-151], [L-159, L-163, L-165, L-166, L-168, L-176, L187, L-190, L-195, and L-196]; (category II) [L-234, L235], [L-318, L-319, L-320, and L-330]; (category III) [L-242, L-245, L-254, L-257, L-258, L-260, L-266, L267, L-269, L-274, L-280, L-293, L-300, L-304], [L-310, L-335], [L-9, L-12, L-17, L-21, L-204, L-214, and L220].

${ }^{b}$ Categorized by a combination of both cultural growth and acetylene reduction tests in a Casamino Acids-minimal medium.

' Only 4 of the original 21 isolates could be categorized by the procedure.

TARLF 3. Physiological differentiation of free-living rhizobia based on acetylene reduction in 5 days

Category III organisms (strain no.)

\section{R. japonicum}

L-241, L-284, L-286, L-292, L-303

L-243, L-250, L-264, L-265, L-277, L-278, L-288, L-301, L-306, L-307

L-248, L-251, L-255, L-256, L-262, L-271, L-272, L-276, L-279, L-290, L-294, L-297, L-298, L-299

L-259, L-302, L-308

Unclassified strains from Phaseoleae plants

L-322, L-332, L-334, L-336, L-337

L-314, L-323, L-324, L-326, L-328, L-329, L-339

L-311

L-315

Other unclassified strains from diverse plants

L-13, L-227, L-344

L-7, L-15, L-18, L-19, L-181, L-212, L-216, L-217

L-2, L-3, L-4, L-14, L-43, L-179, L-180, L-210, L-211, L-221

L-11, L-22

\begin{tabular}{|c|c|c|}
\hline \multirow{2}{*}{$\begin{array}{l}\text { No. of strains } \\
\text { (physiologi- } \\
\text { cal type) }{ }^{a}\end{array}$} & \multicolumn{2}{|c|}{$\begin{array}{c}\text { Range of acetylene reduc- } \\
\text { tion }^{b}(\mathrm{nmol} / \mathrm{ml} \text { of gas sam- } \\
\text { ple) }\end{array}$} \\
\hline & Air & Argon \\
\hline 5 (ia) & $0-2$ & $3-5$ \\
\hline 10 (ib) & $0-5$ & 11 to $>50$ \\
\hline 14 (ic) & $>^{2-10}$ & $\begin{aligned} & 12 \text { to }>50 \\
> & 50\end{aligned}$ \\
\hline $\begin{array}{l}5 \text { (ia, ib) } \\
7 \text { (ic) } \\
1 \text { (ii) } \\
1 \text { (iii) }\end{array}$ & $\begin{aligned} & 0-1 \\
& 1-9 \\
&> 50 \\
& 25\end{aligned}$ & $\begin{aligned} & 2 \text { to }>50 \\
& 10 \text { to }>50 \\
> & 50 \\
& 2\end{aligned}$ \\
\hline $\begin{array}{r}3 \text { (ia) } \\
8 \text { (ib) } \\
10 \text { (ic) } \\
2 \text { (ii) }\end{array}$ & $\begin{array}{l}0 \\
0-5 \\
2-25 \\
>40\end{array}$ & $\begin{aligned} 2-6 \\
4 \text { to }>50 \\
21 \text { to }>50 \\
>50\end{aligned}$ \\
\hline
\end{tabular}

a Physiological types are arbitrary groupings of strains grown on Casamino Acids minimal medium.

${ }^{b}$ Atmosphere containing $10 \%$ acetylene with either $90 \%$ air or argon in $15 \mathrm{ml}$ of gas phase incubated for 5 days. Ethylene formation analyzed by gas chromatography. 
i and ii, with respect to the extent of acetylene reduction in either $90 \%$ air or argon. Type ii organisms were less sensitive to air when incubated for 5 days but, nevertheless, showed considerably less acetylene reduction in air than in argon during a short, 2-day incubation. The comparison strain $32 \mathrm{H} 1$ behaved like a type ii strain when grown on the minimal medium.

\section{DISCUSSION}

Seventy of 272 Rhizobium isolates from leguminous root nodules are fastidious, for they failed to grow in the Casamino Acids-minimal medium used to detect acetylene reduction. $R$. leguminosarum and $R$. phaseoli appear to be of this category (II, Table 2), unable to grow without supplemental nutrients. Since many rhizobia require either biotin, thiamine, or pantothenate (7), these and other nutrient factors that might affect both the growth and acetylene reduction should be reevaluated.

A second category consisting of $R$. meliloti and $R$. trifolii (I, Table 2) may grow on the Casamino Acids medium but gives no acetylene reduction. These strains are analogous to the traditional Rhizobium strains, which are thought to fix nitrogen only in the symbiotic state within root nodules.

A third category (III) consists of (a) $R$. japonicum isolated from soybeans, (b) Rhizobium strains isolated from plants of the Phaseoleae tribe, and (c) unclassified Rhizobium of the cowpea group from a wide variety of plants (4). These strains display variable growth characteristics and acetylene reduction (Table 3 ). In this category, there are at least two distinct physiological types that differ in acetylene reduction when air or argon is the major atmospheric component.

\section{REPRINT REQUESTS}

Address reprint requests to: Dr. C. W. Hesseltine, Northern Regional Research Center, Agricultural Research Service, U.S. Department of Agriculture, Peoria, IL 61604.

\section{LTERATURE CITED}

1. Allen, O. N., E. Hamatova, and F. A. Skinner. 1973. IBP world catalogue of Rhizobium collections. International Biological Programme, Section PP. Knapp, Drewett \& Sons, Ltd., Kingston-upon-Thames, England.

2. Anderson, S. J., and D. A. Phillips. 1976. Effect of protein additives on acetylene reduction (nitrogen fixation) by Rhizobium in the presence and absence of soybean cells. Plant Physiol. 57:890-893.

3. Burris, R. H. 1974. Methodology, p. 9-33. In A. Quispel (ed.), The biology of nitrogen fixation. North-Holland Publishing Co., Amsterdam.

4. De Ley, J., and A. Rassel. 1965. DNA base composition, flagellation and taxonomy of the genus Rhizobium. J. Gen. Microbiol. 41:85-91.

5. Eady, R. R., and J. R. Postgate. 1974. Nitrogenase. Nature (London) 248:805-810.

6. Evans, W. R., and D. L. Keister. 1976. Reduction of acetylene by stationary cultures of free-living Rhizobium sp. under atmospheric oxygen levels. Can. J. Microbiol. 22:949-952.

7. Graham, P. M. 1963. Vitamin requirements of root nodule bacteria. J. Gen. Microbiol. 30:245-248.

8. Hardy, R. W. F., R. D. Holsten, E. K. Jackson, and R. C. Burns. 1968. The acetylene-ethylene assay for $\mathrm{N}_{2}$ fixation: laboratory and field evaluation. Plant Physiol. 43:1185-1207.

9. Heberlein, G. T., J. De Ley, and R. Tijtgat. 1967. Deoxyribonucleic acid homology and taxonomy of Agrobacterium, Rhizobium, and Chromobacterium. J. Bacteriol. 94:116-124.

10. Heywood, W. H. 1971. The Leguminosae-a systematic purview, p. 1-29. In J. B. Harborne, D. Boulter, and B. L. Turner (ed.), Chemotaxonomy of the Leguminosae. Academic Press Inc., New York.

11. Keister, D. L. 1975. Acetylene reduction by pure cultures of rhizobia. J. Bacteriol. 123:1265-1268.

12. Keister, D. L., and W. R. Evans. 1976. Oxygen requirement for acetylene reduction by pure cultures of rhizobia. J. Bacteriol. 129:149-153.

13. Kurz, W. G. W., and T. A. La Rue. 1975. Nitrogenase activity in rhizobia in absence of plant host. Nature (London) 256:407-409.

14. Layne, E. 1957. Spectrophotometric and turbidimetric methods for measuring proteins. Methods Enzymol. 3:448-450.

15. McComb, J. A., J. Elliott, and M. J. Dilworth. 1975. Acetylene reduction by Rhizobium in pure culture. Nature (Iondon) 256:409-410.

16. Oppenheim, J., R. J. Fisher, P. W. Wilson, and L. Marcus. 1970. Properties of a soluble nitrogenase in Azotobacter. J. Bacteriol. 101:292-296.

17. Pagan, J. D., J. J. Child, W. R. Scoweroft, and A. H Gibson. 1975. Nitrogen fixation by Rhizobium cultured on a defined medium. Nature (London) 256:406-407.

18. The American Type Culture Collection. 1974. Medium 111, p. 274. In Catalogue of strains. American Type Culture Collection, Rockville, Md.

19. Tjepkema, J., and H. J. Evans. 1975. Nitrogen fixation by free-living Rhizobium in a defined liquid medium. Biochem. Biophys. Res. Commun. 65:625-628.

20. Vincent, J. M. 1974. Root-nodule symbioses with $R$ hizobium, p. 266-341. In A. Quispel (ed.), The biology of nitrogen fixation. North-Holland Publishing Co., Amsterdam.

21. Werner, D., and K. Berghäuser. 1976. Discrimination of Rhizobium japonicum, Rhizobium lupini, Rhizobium trifolii, Rhizobium leguminosarum and of bacteroids by uptake of 2-ketoglutaric acid, glutamic acid and phosphate. Arch. Microbiol. 107:257-262.

22. Yates, M. G., and C. W. Jones. 1974. Respiration and nitrogen fixation in Azotobacter. Adv. Microb. Physiol. 11:97-135. 